\title{
Tradisi Pohulo'o Pada Masyarakat Gorontalo Perspektif Hukum Ekonomi Syariah
}

\author{
Rizal Darwis \\ Fakultas Syariah IAIN Sultan Amai Gorontalo \\ rizaldarwis@iaingorontalo.ac.id
}

\begin{abstract}
This study discusses about the Islamic economic law system in the practice of pohulo'o in Gorontalo society. This study is examined through normative and socio-cultural approaches. Data obtained from interviews, documentation and questionnaires with 150 respondents. The results of the study show that: First, the practice of pohulo'o has basically produced a lot of pawn (al-rahn) in the sharia economic legal system, both related to harmony and its requirements; Second, the relevance of pohulo'o between the concept of al-rahn in the Islamic economic law system is related to: (a) the existence of a contract from the terms and conditions which have similarities; (b) the practice of pohulo'o with conservation of pawnshops (upilohulo'o) which tends to be carried out by the pawn holder (popohulo'o), although it is a pawn (tampohulo'o) and may also use it. However, in this case it depends on the agreement or contract that has been made. Ulama differs their views on this matter.
\end{abstract}

Keywords: Gorontalo's society; law of Islamic economy; local tradition

\begin{abstract}
Abstrak
Penelitian ini membahas sistem hukum ekonomi syariah dalam praktik pohulo'o pada masyarakat Gorontalo dan dikaji melalui pendekatan normatif dan pendekatan sosio-budaya. Data dikumpulkan melalui observasi, wawancara, dokumentasi dan angket dengan jumlah sampel 150 responden. Hasil penelitian menunjukkan bahwa praktik pohulo'o yang terjadi pada masyarakat petani Gorontalo pada dasarnya telah memenuhi unsur-unsur gadai (rahn) dalam sistem hukum ekonomi syariah, baik terkait rukun maupun syarat-syaratnya. Relevansi pohulo'o dengan konsep rahn dalam sistem hukum ekonomi syariah; (a) akad dimana unsur-unsur rukun dan syaratsyaratnya memiliki persamaan; (b) praktik pohulo'o dengan pemanfaatan barang gadai (upilohulo'o) kecenderungannya dilakukan oleh pemegang gadai (popohulo'o), walaupun penggadai (tampohulo'o) juga boleh memanfaatkannya. Namun dalam hal ini tergantung atas kesepakatan atau akad perjanjian yang telah dibuat. Perbedaan ini pada dasarnya dapat dilihat dari adanya perbedaan pandangan para fukaha dalam melihat jenis barang jaminan tersebut.
\end{abstract}

\section{Kata kunci: hukum ekonomi Islam; masyarakat Gorontalo; tradisi lokal}

\section{A. Pendahuluan}

Indonesia merupakan salah satu negara yang dilalui oleh garis khatulistiwa, ini berarti Indonesia memiliki iklim tropis dengan struktur tanah yang cenderung subur. Kesuburan itulah menjadikan Indonesia sebagai negara agraris di mana penduduknya sebagian besar bermata pencaharian sebagai petani, sehingga sebagian penduduknya sangat menggantungkan hidupnya dari sektor pertanian. Selain itu juga terkait dengan kepemilikan tanah pertanian yang merupakan aset yang sangat menunjang dalam kehidupan perekonomian masyarakat agraris tersebut.

Provinsi Gorontalo adalah salah satu provinsi yang berada pada wilayah Timur Indonesia dengan wilayahnya terbagi atas Kota Gorontalo, Kabupaten Gorontalo, Kabupaten Bone Bolango, Kabupaten Boalemo, Kabupaten Gorontalo Utara, dan 
Kabupaten Pohowato yang sebagian wilayahnya adalah lahan pertanian. Ini tentunya menjadikan salah satu bentuk mata pencaharian dari masyarakat Gorontalo adalah bertani dan bercocok tanam dengan luas lahan pertanian tahun 2015 berkisar 32.058 ha. ${ }^{1}$

Tanah pertanian yang merupakan aset harta dapat dijadikan sebagai salah satu obyek transaksi dalam sistem perekonomian masyarakat. Praktik transaksi yang berkaitan dengan tanah sering dijumpai di dalam masyarakat petani, misalnya jual beli tanah, sewa tanah, bagi hasil dengan obyek tanah, gadai tanah dan lain sebagainya.

Perjanjian gadai dalam fikih Islam diistilahkan dengan al-rahn, yaitu perjanjian menahan suatu barang sebagai tanggungan utang. Al-rahn sering diidentikkan dengan gadai syariah, yang secara bahasa diartikan al-tsubut wa al-dawam (tetap dan kekal). Sebagian ulama luhgat memberi arti al-hab (tertahan). Sedangkan definisi al-rahn menurut istilah adalah menjadikan suatu benda yang mempunyai nilai harta dalam pandangan syara' untuk kepercayaan suatu utang, sehingga memungkinkan mengambil seluruh atau sebagian utang dari benda gadai itu. ${ }^{2}$

Pada mulanya, praktik gadai tanah dijumpai dalam masyarakat adat dengan peraturan yang ditentukan dalam hukum Adat. Tiap masyarakat adat, menyebut gadai dengan istilah yang berbeda, misalnya menggadai (Minangkabau), adol sande (Jawa), ngajual akad/gade (Sunda). Dari kacamata hukum Adat, gadai tanah merupakan penyerahan tanah untuk menerima pembayaran sejumlah uang secara tunai, dengan ketentuan si penjual tetap berhak atas pengembalian tanahnya dengan jalan menebusnya kembali. ${ }^{3}$ Masyarakat Gorontalo mengenal gadai tanah dengan istilah pohulo'o.

Praktik pohulo'o pada masyarakat Gorontalo telah dilaksanakan sejak dahulu kala. Alasan masyarakat Gorontalo melakukan praktik pohulo'o disebabkan adanya kebutuhan ekonomi yang mendesak, di mana pelaksanaan pohulo'o agak mudah secara administratif dibandingkan melakukannya pada lembaga pegadaian yang resmi.

Persoalannya kemudian di dalam praktik pohulo'o adalah pemilik (al-rahin) menggadaikan barangnya kepada penggadai (murtahin) dengan kesepakatan jika murtahin yang mengelola barang yang digadaikan, maka al-rahin tidak mendapatkan hasil dari panen, tetapi jika al-rahin yang mengelola maka murtahin mendapatkan 1/3 dari hasil panen. Dalam kasus ini, Islam mengenal perjanjian tersebut dengan sistem rahn dan muzara'ah.

Mekanisme yang lain, al-rahin menggadaikan lahan kepada murtahin dengan perjanjian bahwa lahan yang digadaikan diolah selama beberapa musim atau beberapa tahun. Setelah jatuh tempo, maka murtahin mengembalikan barang jaminan kepada alrahin atau dalam istilah Gorontalo disebut pajaki. Dalam Islam, proses tersebut dikenal dengan ijarah (sewa-menyewa). Tentunya mekanisme ini mengalami pergeseran dari bentuk perjanjian al-rahn dengan perjanjian yang lain yaitu ijarah (sewa-menyewa), dan juga petani pemilik (al-rahin) berubah status menjadi petani penggarap, bahkan menjadi buruh tani dari tanah gadaiannya. Padahal dalam konsep fikih, al-rahn dilaksanakan adalah untuk saling membantu antara sesama manusia, khususnya umat Islam dalam menyelesaikan persoalan pemenuhan ekonomi masyarakat. Inilah yang kemudian menjadi starting point diangkatnya penelitian ini. Penelitian ini terkait dengan sistem ekonomi yang dilaksanakan oleh masyarakat Gorontalo dalam hal gadai tanah (pohulo'o).

\footnotetext{
${ }^{1}$ Badan Pusat Statistik Provinsi Gorontalo, Provinsi Gorontalo dalam Angka 2016, Gorontalo Province In Figures 2016 (Gorontalo: Badan Pusat Statistik Provinsi Gorontalo, 2016), h. 159.

${ }^{2}$ Abdul Ghofur Anshori, Gadai Syari'ah di Indonesia (Yogyakarta: Gadjah Mada University Press, 2005), h. 88.

${ }^{3}$ Imam Sudiyat, Asas-Asas Hukum Adat: Bekal Pengantar (Yogyakarta: Liberty, 1981), h. 28. 
Penelitian ini sangat penting dilaksanakan untuk mencermati akulturasi nilai-nilai kearifan lokal dengan nilai-nilai agama Islam dalam konsep hukum ekonomi syariah (figh muamalat).

Beberapa penelitian telah dilakukan terkait dengan gadai tanah, misalnya: penelitian dari Aliasman dengan judul Pelaksanaan Gadai Tanah dalam Masyarakat Hukum Adat Minangkabau di Nagari Campago Kabupaten Padang Pariaman Setelah Berlakunya Pasal 7 UU No. 56/Prp/1960. Hasil penelitiannya menunjukkan praktik gadai tanah dilakukan dalam keadaan terdesak dan dengan maksud tolong-menolong, sehingga tidak ada unsur pemerasan dalam praktik tersebut. ${ }^{4}$

Penelitian dari Safrizal dengan judul Praktek Gala Umong (Gadai Sawah) dalam Perspektif Syari'ah (Studi Kasus di Desa Gampong Daya Syarif Kecamatam Mutiara Kabupaten Pidie Provinsi Aceh). Hasil penelitian menunjukkan adanya praktik gadai sawah pada masyarakat Desa Gampong Daya Syarif dalam hal batas pengembalian hutang gadai belum jelas, sehingga hal ini menimbulkan perselisihan. ${ }^{5}$

Penelitian dari Aermadepa dengan judul Perlindungan Hak Konstitusional Masyarakat Hukum Adat Minangkabau dalam Pelaksanaan Gadai Tanah Pertanian. Hasil penelitiannya menunjukkan secara konstitusi, negara mengakui keberadaan hak masyarakat hukum adat, namun di sisi lain ada peraturan perundangan-undangan yang kontraproduktif dengan jaminan hak tersebut. Dalam pelaksanaan gadai tanah pertanian secara adat di Minangkabau Sumatera Barat pelaksanaan gadai tidaklah sebagaimana sistim ijon yang syarat pemerasan tapi juga berlandaskan tolong menolong dan harga gadai juga sudah mendekati harga jual tanah. ${ }^{6}$

Penelitian Sofhian dan Asna Usman Dilo dengan judul Tradisi Pohulo'o Gorontalo dalam Tinjauan Fiqh. Hasil penelitiannya menunjukkan tradisi pohulo'o (gadai) tidak sesuai dengan gadai ( $r a h n)$ ) dalam kajian fiqh. Ada perbedaan yang sangat mendasar yakni dari segi pemanfaatan lahan, harta yang digadaikan dan risiko yang ditimbulkan akibat praktek pohulo'o itu sendiri, dimana merugikan salah satu pihak yaitu pemberi gadai (rahin) ${ }^{7}$

Penelitian dari Nur Ridwan Ari Sasongko dengan judul Gadai Tanah/ Sawah menurut Adat dari Masa ke Masa. Penelitiannya mencermati bahwa pelaksanaan gadai tanah harus sesuai dengan pasal 7 UU No. 56/Prp/1960, yaitu menurut hukum adat memindahtangankan tanah itu baru boleh dilaksanakan apabila keadaan yang mendesak, yaitu dalam hal membahayakan atau akan mendatangkan aib bagi keluarga. ${ }^{8}$

Penelitian ini akan mencermati akulturasi aspek tradisi/budaya/kearifan lokal dengan perkembangan sistem hukum ekonomi syariah (fikih muamalah) dan juga menganalisis pergeseran dari akad rahn (gadai) menjadi akad ijarah (sewa-menyewa)

\footnotetext{
${ }^{4}$ Aliasman, "Pelaksanaan Gadai Tanah dalam Masyarakat Hukum Adat Minangkabau di Nagari Campago Kabupaten Padang Pariaman Setelah Berlakunya Pasal 7 UU No. 56/Prp/1960,“ Tesis (Semarang: Pascasarjana Universitas Diponegoro, 2005).

${ }^{5}$ Safrizal, "Praktek Gala Umong (Gadai Sawah) dalam Perspektif Syari'ah (Studi Kasus di Desa Gampong Daya Syarif Kecamatam Mutiara Kabupaten Pidie Provinsi Aceh), “ Jurnal Ilmiah Islam Futura, Vol. 15. No. 2, Februari 2016.

${ }^{6}$ Aermadepa, "Perlindungan Hak Konstitusional Masyarakat Hukum Adat Minangkabau dalam Pelaksanaan Gadai Tanah Pertanian,“ Jurnal Konstitusi, Volume 13, Nomor 3, September 2016.

${ }^{7}$ Sofhian dan Asna Usman Dilo, "Tradisi Pohulo'o Gorontalo dalam Tinjauan Fiqh," el Harakah, Vol. 15, No. 1 Tahun 2013.

${ }^{8}$ Nur Ridwan Ari Sasongko, "Gadai Tanah/ Sawah menurut Adat dari Masa ke Masa,“ Jurnal Repertorium, Vol. 1, No. 2, November 2014.
} 
yang dilakukan oleh masyarakat Gorontalo, sehingga dapat diketahui relevansi rahn dalam Islam dengan pohulo'o dalam adat Gorontalo.

\section{B. Akad Pinjam Meminjam dalam Islam}

Dalam kegiatan pinjam meminjam yang terjadi di masyarakat pada umumnya masih mempersyaratkan adanya penyerahan jaminan utang oleh pihak peminjam kepada pihak pemberi pinjaman. Jaminan utang ini dapat berupa barang, sehingga barang tersebut merupakan jaminan kebendaan dan adanya jaminan kebendaan ini memberikan hak kebendaan kepada pemegang jaminan tersebut. Bahsan mengemukakan bahwa kegiatan pinjam meminjam uang sebagai sesuatu yang sangat diperlukan dalam mendukung pekembangan kegiatan ekonomi dan sebagai cara meningkatkan taraf kehidupan dalam masyarakat, di mana pihak pemberi pinjaman yang mempunyai kelebihan uang bersedia memberikan pinjaman uang kepada yang memerlukannya. Sedangkan pihak peminjam dapat terbantukan sesuai keperluan dan tujuan dalam melakukan pinjaman. ${ }^{9}$

Kegiatan pinjam meminjam yang mempersyaratkan adanya penyerahan jaminan biasanya dikenal dengan istilah gadai. Menurut Sulaiman Rasyid, gadai adalah akad utang di mana terdapat suatu barang yang dijadikan peneguhan atau penguat kepercayaan dalam utang piutang, barang itu boleh dijual kalau utang tak dapat dibayar, hanya penjual itu hendaknya dengan keadilan (dengan harga yang berlaku di waktu itu). ${ }^{10}$ Sayyid Sabiq juga mengemukakan bahwa gadai adalah menjadikan barang yang mempunyai nilai harta menurut syara' sebagai jaminan utang, sehingga orang yang bersangkutan boleh mengambil utang atau bisa mengambil sebagian (manfaat) barang itu. ${ }^{11}$

Pada masyarakat dengan wilayah pertanian dan perkebunan biasanya menerapkan sistem gadai tanah. Rachmadi Usman mengemukan bahwa gadai dapat diartikan menyerahkan tanah dari penggadai (pemilik tanah) kepada pemegang gadai untuk menerima pembayaran sejumlah uang secara tunai dari pemegang gadai dengan ketentuan penggadai tetap berhak atas pengembalian tanahnya dengan jalan menebusnya kembali dari pemegang gadai, dan pada dasarnya besaran uang tebusan adalah sama dengan uang yang diserahkan pemegang gadai pada awal transaksi gadai kepada penjual gadai, tidak ada perbedaan nominal uang. ${ }^{12}$

Gadai adalah hubungan hukum antara seseorang dengan tanah kepunyaan orang lain yang telah menerima uang gadai daripadanya. Selama uang gadai belum dikembalikan, maka tanah tersebut tetap dikuasai oleh pemegang gadai. Pengembalian uang gadai sebagai tebusan tergantung pada kemauan dan kemampuan pemilik tanah yang menggadaikan.

Pinjam meminjam dengan cara gadai ini adalah salah satu bentuk dinamika sosial dan ekonomi yang mengarah perbuatan hukum yang terjadi di masyarakat ini dan merupakan sebuah bentuk dari refleksi hukum. Durkheim sebagai dikutip Sukanto menyatakan hukum itu adalah refleksi dari solidaritas sosial masyarakat, baik itu bersifat mekanis maupun organis. Solidaritas mekanis ini pada masyarakat sederhana dan homogen di mana ikatan warganya didasarkan atas hubungan-hubungan pribadi

${ }^{9}$ M. Bahsan, Hukum Jaminan dan Jaminan Kredit Perbankan Indonesia (Jakarta: Rajawali Press, 2007, h. 2.

${ }^{10}$ Sulaiman Rasyid, Fiqih Islam (Bandung: PT. Sinar Baru Algensindo, 1994), h. 309.

${ }^{11}$ Sayid Sabiq, Fiqh Sunnah, Jilid 12 (Jakarta: Pustaka Percetakan Offset, 1998), h. 139.

${ }^{12}$ Rachmadi Usman, Hukum Jaminan Keperdataan (Jakarta: Sinar Grafika, 2003), h. 120. 
serta tujuan yang sama. Sedangkan solidaritas organis pada masyarakat heterogen dengan pembagian kerja yang kompleks. ${ }^{13}$

Penerapan konsep pinjam meminjam dengan jaminan tanah sebagai gambaran fungsi hukum yang terjadi dalam kehidupan masyarakat. Friedman Lawrence sebagaimana dikutip Taneko pernah menyebutkan bahwa fungsi hukum dalam kehidupan bermasyarakat, yaitu alat pengawasan/pengendalian sosial (social control), alat penyelesaian sengketa (dispute settlement), dan alat rekayasa sosial (social engginering, redistributive, innovative). ${ }^{14}$ Ketiga bentuk fungsi hukum di atas adalah berperan untuk memberikan petunjuk kepada masyarakat untuk bagaimana harus bertingkah laku, dengan melihat mana sesuatu yang dibolehkan oleh hukum dan mana sesuatu yang tidak dibolehkan oleh hukum.

Pelaksanaan suatu perikatan tidak terlepas dari adanya rukun dan syarat, begitu pula halnya gadai (al-rahn) yang harus dipenuhi. Menurut hukum Islam, rukun gadai ( $a l$ rahn) terdiri atas 4 rukun, yaitu: (1) sighat (ijab dan qabul), (2) pihak yang mengadakan akad (aqid), yaitu orang yang menggadaikan (rahin) dan yang menerima gadai (murtahin), (3) barang yang digadaikan (marhun), dan (4) hutang (marhun bih). ${ }^{15}$ Kelengkapan daripada rukun gadai ini merupakan hal yang sangat penting akan sah tidaknya pelaksanaan gadai tersebut.

\section{Praktik Pelaksanaan Tradisi Pohulo’o Dalam Masyarakat Gorontalo}

Masyarakat Gorontalo mengenal dua bentuk pertanian berdasarkan jenis tempat dan tanamannya, yakni ladang dan sawah. Ladang adalah kawasan pertanian kering, yang umumnya ditanami sayur-sayuran, umbi-umbian, dan palawija, sementara sawah adalah kawasan pertanian basah yang ditanami padi.

Dalam fikih Islam, pengolahan lahan pertanian bisa dalam bentuk musaqah, muzara'ah dan mukhabarah. Musaqah menurut ulama fikih adalah akad penyerahan kebun (pohon-pohonan) kepada petani untuk digarap dengan ketentuan bahwa buahbuahan (hasilnya) dimiliki berdua (pemilik dan petani). ${ }^{16}$ Muzara'ah adalah akad kerjasama dalam bidang pertanian di mana pemilik tanah memberikan tanahnya kepada pihak pengelola dan bibitnya dari pihak pemilik tanah, serta bagi hasilnya sesuai kesepakatan kedua belah pihak. ${ }^{17}$ Mukhabarah adalah akad kerjasama dalam bidang pertanian di mana modalnya berasal dari pengelola. ${ }^{18}$

Masyarakat Gorontalo dalam kesehariannya telah melakukan aktifitas ekonomi sesamanya, baik itu jual beli, sewa-menyewa, pinjam-meminjam, maupun gadai. Hal ini dapat dilihat dari penyebaran angket kepada para informan tentang pengetahuan istilah gadai, dimana $100 \%$ masyarakat telah melakukan aktivitas gadai/pohulo'o. Ini

\footnotetext{
${ }^{13}$ Soerjono Soekanto, Sosiologi: Suatu Pengantar (Jakarta: RajaGrafindo, 2009), h. 155.

${ }^{14}$ Soleman B. Toneko, Struktur dan Proses Sosial (Cet. II; Jakarta: RajaGrafindo Persada, 1993), h. 37 .

${ }^{15}$ Hendi Suhendi, Fiqh Muamalah (Cet. I; Jakarta: Rajawali Pers, 2014), h. 107-108.

${ }^{16}$ M. Ali Hasan, Berbagai Macam Transaksi dalam Islam (Fiqh Muamalat), Ed. 1 (Cet. I; Jakarta: PT RajaGrafindo Persada, 2003), h. 280.

${ }^{17}$ Rizal Darwis, "Sistem Bagi Hasil Pertanian Berbasis Kearifan Lokal Pada Masyarakat Petani Penggarap di Kabupaten Gorontalo Perspektif Hukum Ekonomi Islam, ” Penelitian (Gorontalo: Lembaga Penelitian IAIN Sultan Amai Gorontalo, 2016), h. 34.

${ }^{18}$ Rizal Darwis, "Sistem Bagi Hasil Pertanian Berbasis Kearifan Lokal," h. 35.
} 
menandakan bahwa istilah gadai dalam kehidupan keseharian masyarakat Gorontalo bukanlah istilah asing.

Tradisi pohulo'o pada sawah pertanian adalah salah satu tradisi yang telah lama berkembang di Gorontalo dan masih dilakukan oleh masyarakat petani Gorontalo. Tradisi pohulo'o telah dilaksanakan sejak dahulu kala atau sejak nenek moyang suku Gorontalo sebagaimana jawaban angket dari 115 orang atau $76,7 \%$. Selain itu yang menjawab tradisi pohulo'o sudah ada sebelum Islam masuk di Gorontalo sebanyak 12 orang atau 8\%, dan yang menjawab tradisi pohulo'o sudah setelah Islam masuk di Gorontalo sebanyak 23 orang atau $15,3 \%$.

Hasil wawancara Bapak H. Dedi. K. Usman bahwa "tidak ada data yang jelas mengenai kapan tradisi pohulo'o ini dimulai, namun perlu diketahui bahwa tradisi ini sudah ada sejak nenek moyang suku Gorontalo ada, di mana tradisi ini turun-temurun dilakukan bagi masyarakat Gorontalo yang ingin menggadaikan hartanya, seperti sawah atau ladangnya." 19 Juga diungkapkan oleh K. H. Abdul Rasyid Kamaru bahwa "Keberadaan praktik pohulo'o di Gorontalo pastilah sebelum masuknya ajaran Islam di Gorontalo. Namun saja praktik pohulo'o ini pada prinsipnya nilai-nilai yang tertanam didalamnya adalah saling membantu antara sesama, dan ini sangat erat kaitannya dengan perintah dalam agama Islam untuk saling tolong menolong dalam kebaikan." 20

Praktik pohulo'o di Gorontalo melibatkan dua pihak, yaitu pihak pemberi gadai dan pihak yang menerima gadai. Barang-barang yang digadaikan umumnya barangbarang yang bernilai tinggi dan menguntungkan, terutama berupa sawah. Penentuan sawah ini disebabkan para pemegang gadai tidak mau jika barang yang dijadikan jaminan tidak menguntungkan bagi mereka.

Praktik pohulo'o yang dilakukan oleh masyarakat Gorontalo pada prinsipnya sangat mudah dilakukan, di mana penggadai mendatangi pemegang gadai. Informan yang menjawab mudah sebanyak 39 orang atau 26\%; informan yang menjawab sangat mudah sebanyak 75 orang atau 50\%; informan yang menjawab biasa-biasa saja sebanyak 20 orang atau 13,3\%; informan yang menjawab sulit sebanyak 11 orang atau 7,3\%; dan informan yang menjawab sangat sulit sebanyak 5 orang atau 3,4\%.

Masyarakat petani Gorontalo sebagian besar telah mengetahui unsur atau rukun pohulo'o. Informan yang menjawab mengetahui sebanyak 94 orang atau 62,7\%; informan yang menjawab kurang mengetahui sebanyak 30 orang atau $20 \%$; sedangkan informan yang menjawab tidak mengetahui sebanyak 26 orang atau $17,3 \%$. Wawancara dengan Bapak "H" bahwa "unsur-unsur dari pohulo'o (gadai) tersebut, yaitu ada tampohulo'o (penggadai), ada popohulo'o (pemegang gadai), ada upilohulo'o atau barang jaminan, ada mobuli atau hutang, dan ada dandia atau akaji atau akad perjanjian atau ijab qabul." 21

Praktik pohulo'o pada masyarakat Gorontalo dilakukan dengan cara petani yang ingin menggadaikan tanahnya langsung datang ke orang yang biasa memegang gadai sawah dan ketika terjadi kesepakatan, maka terjadilah transaksi. Artinya bahwa praktik pohulo'o yang terjadi di kalangan masyarakat petani di Gorontalo pada umumnya dilaksanakan antar individu, dan jarang melaksanakannya di lembaga keuangan. Praktik

${ }^{19}$ H. Dedi K. Usman, Tokoh Adat Gorontalo, Focus Group Discussion, di Grand City Hotel, Gorontalo, tanggal 4 Oktober 2017.

${ }^{20}$ K. H. Abdul Rasyid Kamaru, Tokoh Agama, Focus Group Discussion, di Grand City Hotel, Gorontalo, tanggal 4 Oktober 2017.

${ }^{21}$ Bapak "H," Masyarakat Petani, Wawancara, di Bongememe, Kabupaten Gorontalo, tanggal 16 Oktober 2017. 
pohulo'o juga ada yang dilakukan secara tertulis, yaitu dengan adanya surat gadai yang dilakukan oleh penggadai dan yang menerima gadai, dengan dihadiri oleh dua orang saksi, dan biasanya dibuat di atas materai, ditandatangani oleh kedua belah pihak dan saksi-saksi.

Obyek yang dijadikan jaminan dalam praktik pohulo'o menurut masyarakat Gorontalo dapat berupa benda bergerak dan benda tidak bergerak. Masyarakat Gorontalo lebih dominan menggadaikan benda tidak bergerak yang dimilikinya. Hal ini diketahui dengan jawaban informan sebanyak 96 orang atau 64\%, dan yang menjawab benda bergerak sebanyak 54 orang atau 36\%. Benda-benda bergerak yang dimaksudkan adalah binatang ternak, seperti sapi, kuda dan kambing. Sedangkan benda-benda tidak bergerak, seperti sawah, ladang/kebun, mobil, motor, emas, dan lain-lain.

Pelaksanaan pohulo'o memiliki batasan waktu sebagaimana disepakati oleh pihak yang melakukan pohulo'o. Dari 150 informan atau 100\% menjawab adanya batasan waktu dalam pohulo'o yang dilakukan oleh masyarakat Gorontalo. Batasan waktu itu beragam dengan melihat waktu panen yang dilakukan oleh para petani tersebut. Jangka waktu pelaksanaan pohulo'o dilihat berdasarkan masa musim panen. Informan yang menjawab 1 kali musim panen sebanyak 32 orang atau $21,3 \%$; informan yang menjawab 2 kali musim panen sebanyak 94 orang atau 62,7\%; informan yang menjawab 3 kali musim panen sebanyak 14 orang atau 9,3\%; dan informan yang menjawab 4 kali musim panen sebanyak 19 orang atau 6,7\%. Adanya perbedaan waktu ini dikarenakan pada daerah-daerah tertentu di Gorontalo dalam memperoleh hasil panen beragam pula sesuai masa tanam yang dilakukan masyarakat tersebut. Tentunya hal ini berimbas ketika mereka menggadaikan (mopohulo'o) tanah atau sawah mereka dengan jangka waktu yang berbeda-beda pula.

Wawancara dengan Bapak "N" menyebutkan bahwa "Jangka waktu dan pemanfaatan lahan yang sudah di pohulo'o bervariasi. Ada yang menentukan waktu pohulo'o empat kali panen, dengan lahan yang digadaikan dikelolah oleh yang memegang pohulo'o. Sekiranya jika setahun dua kali panen, maka waktunya dua tahun, namun bila dalam satu tahun terjadi musim kemarau dan hanya sekali panen, maka bisa jadi mencapai empat tahun. Kesepakatan yang terjadi antara penggadai dan pemegang gadai adalah empat kali musim panen dan bukan berdasarkan tahun."22 Juga dipaparkan oleh Bapak "E" bahwa " lain lagi jika pada musim panen berjalan dengan lancar, maka proses penebusan lahan dapat dilakukan hanya dalam jangka waktu dua tahun. Pada intinya perjanjian pohulo'o dihitung berdasarkan musim panen bukan tahun. tetapi pada umumnya perjanjian didasarkan pada besaran jumlah uang yang mereka pinjamkan. Jika sudah empat musim, tetapi pemegang pohulo'o belum mempunyai uang maka penggadai mendatangi pemegang pohulo'o untuk memperpanjang jangka waktu penebusan lahan.“23

Dalam sistem pohulo'o, masyarakat Gorontalo menambah jumlah pinjaman gadai dengan variasi jawaban yang menjawab ada kemungkinan adalah 74,4\% (112 orang) dan jawaban tidak mungkin 25,3\% (38 orang). Ini menjelaskan bahwa selama pohulo'o berlangsung, penambahan uang gadai juga dimungkinkan apabila disepakati oleh kedua belah pihak. Dalam penambahan gadai ini biasanya tidak boleh lebih besar dari harga

\footnotetext{
${ }^{22}$ Bapak "N," Masyarakat Petani, Wawancara, di Kecamatan Telaga Biru, Kabupaten Gorontalo, tanggal 9 Oktober 2017.

${ }^{23}$ Bapak "E," Masyarakat Petani, Wawancara, di Bongememe, Kabupaten Gorontalo, tanggal 16 Oktober 2017.
} 
gadai yang pertama, karena dalam transaksi gadai tersebut, tidak bisa sesuai keinginan dari penggadai saja, akan tetapi pemegang gadai juga memperhitungkan luas dari objek gadai tersebut, yaitu uang gadai tidak boleh melebihi harga jual dari objek gadai tersebut.

Masyarakat Gorontalo dalam perjanjian pohulo'o melakukannya, baik secara lisan, tertulis, disaksikan oleh saksi, maupun kombinasi ketiga-tiganya. Informan yang menjawab pelaksanaan perjanjian pohulo'o dilakukan secara lisan sebanyak 19 orang atau 12,7\%; yang menjawab secara tertulis sebanyak 40 orang atau 26,7\%; yang menjawab lisan dan ada saksi sebanyak 44 orang atau 29,3\%; dan yang menjawab tertulis dan ada saksi sebanyak 47 orang atau 31,3\%. Gambaran ini menunjukkan bahwa pohulo'o yang dipraktikkan masyarakat Gorontalo adalah salah satu bentuk perjanjian yang berakibat hukum, saling mengikat antara kedua belah pihak.

Terkait dengan pemanfaatan barang gadai dalam tradisi pohulo'o dalam masyarakat Gorontalo ada yang membolehkan dan ada yang tidak membolehkan. Selain itu pihak-pihak yang mengolah atau memanfaatkan boleh oleh penggadai, atau pemegang gadai itu sendiri. Adanya kebolehan pemanfaatan barang gadai dijawab informan sebanyak 143 orang atau 95,3\% dan informan yang tidak membolehkan sebanyak 7 orang atau 4,7\%. Data ini didukung dengan hasil wawancara dengan Bapak "G" bahwa "Saya mendatangi Bapak "J" yang biasa menerima gadai untuk meminjam uang dengan jaminan sawah dan kesepakatan bahwa sawah itu diolah oleh dia selama 1 kali panen. ${ }^{24}$

Pihak pengelolah barang gadai dalam pohulo'o pada masyarakat Gorontalo adalah pihak pemegang gadai dengan jawaban informan sebanyak 126 orang atau 84\%; sedangkan pihak penggadai dijawab oleh informan sebanyak 24 orang atau $16 \%$. Pemanfaatan barang gadai bisa dilakukan, baik oleh penggadai sendiri, pemegang gadai, maupun kedua-duanya secara bersamaan. Hal ini dilihat dari informan yang menjawab: pihak penggadai sebanyak 37 orang atau 24,6\%; pemegang gadai sebanyak 94 orang atau $62,7 \%$; dan kedua-duanya sebanyak 19 orang atau $12,7 \%$. Jawaban ini tentunya dapat dipahami bahwa pada prinsipnya pemanfaatan dari barang gadai oleh siapa saja, baik itu penggadai, pemegang gadai atau kedua-duanya secara bersamaan tergantung dari kesepakatan awal yang dibangun ketika melakukan akad perjanjian pohulo'o.

Pemanfaatan barang gadai pada tradisi pohulo'o oleh pemegang gadai dalam masyarakat Gorontalo masih didapati adanya ketidaksetujuan atau keberatan dari penggadai. Pemanfaatan barang gadai oleh pemegang gadai menurut tanggapan penggadai adalah merugikan, sebagai hasil jawaban informan yang menjawab merugikan sebanyak 83 orang atau 55,3\%; yang menjawab tidak merugikan sebanyak 46 orang atau $30,7 \%$; yang menjawab ragu-ragu sebanyak 21 orang atau $14 \%$.

Penggadai yang merasa dirugikan disebabkan mereka tidak dapat lagi mengolah sawah yang digadaikannya, sehingga berujung juga pada menurunnya sumber pendapatan mereka sebagai petani. Sedangkan penggadai yang tidak merasa dirugikan berpandangan bahwa hal itu sudah wajar karena mereka telah berutang dan sebelum berhasil menyelesaikan utangngya, maka pihak pemegang gadai boleh memanfaatkan barang yang digadaikan tersebut.

Pohulo'o adalah sebuah praktik yang melibatkan 2 orang atau lebih, maka tidak bisa dipungkiri terjadinya konflik atau sengketa antara kedua belah pihak. Sengketa dalam tradisi pohulo'o kurang terjadi, sebagaimana jawaban informan dari pengisian angket bahwa yang menjawab ya sebanyak 33 orang atau $22 \%$ dan yang menjawab tidak

${ }^{24}$ Bapak "G," Masyarakat Petani, Wawancara, di Mananggu, Kabupaten Boalemo, tanggal 19 Oktober 2017. 
sebanyak 117 orang atau $78 \%$. Ini menandakan bahwa dalam diri masyarakat petani Gorontalo telah tertanam saling kepercayaan, pemenuhan hak dan kewajiban, sehingga hal-hal yang terkait dengan sengketa pohulo'o sangat diminimalisir. Namun, jika terjadi sengketa maka pihak-pihak bersengketa tersebut melakukan langkah-langkah penyelesaian. Masyarakat petani Gorontalo dalam menyelesaikan sengketa pohulo'o dominan melakukan musyawarah mufakat dibandingkan melalui jalur persidangan. Hal ini dilihat dari jawaban informan yang menjawab melalui musyawarah mufakat sebanyak 132 orang atau $88 \%$ dan menjawab melalui proses persidangan/peradilan sebanyak 18 orang atau $22 \%$.

Wawancara dengan H. Dedi K. Usman mengatakan bahwa "Suku Gorontalo sangat kental dengan budaya dan adat istiadatnya. Mereka dalam melakukan aktifitas terkait orang banyak dilakukan secara musyawarah dan mufakat. Dalam budaya Gorontalo dikenal istilah modoluhupa. Inilah yang mengikat masyarakat Gorontalo apabila terjadi percekcokan atau persengketaan. ${ }^{25}$

Pada prinsipnya praktik pohulo'o (gadai) yang dilakukan oleh masyarakat petani Gorontalo terbagi atas 2 bentuk praktik, yaitu:

1. Gadai biasa, yaitu akad kesepakatan antara penggadai (pemilik sawah) dengan pemegang gadai, di mana penggadai meminjam uang dan barang gadai dipegang, diolah dan hasilnya dinikmati oleh pemegang gadai dalam waktu 1 tahun, dan apabila selama 1 tahun belum dilunasi maka tetap diolah oleh pemegang gadai.

2. Gadai pajaki, yaitu akad kesepatakan antara penggadai (pemilik sawah) dengan pemegang gadai, di mana penggadai (pemilik sawah) bisa menggarap sawahnya, dan penggadai tetap membayar uang sewa kepada pemegang gadai sebesar harga yang disepakati sampai penggadai bisa melunasi pokok hutangnya.

Gambaran praktik pohulo'o yang dilakukan oleh masyarakat petani Gorontalo merupakan sebuah potret kerjasama dan kesepakatan antara dua pihak yang saling menguntungkan dan menjadi cara yang mudah bagi pihak-pihak tertentu untuk mendapatkan pinjaman.

\section{Relevansi Tradisi Pohulo'o dalam Masyarakat Gorontalo Dengan Konsep Al- Rahn dalam Sistem Hukum Ekonomi Syariah}

Banyak realitas yang terjadi di masyarakat yang tidak memiliki dasar nash Alquran maupun hadis Nabi saw., akan tetapi hal itu sudah menjadi adat kebiasaan (al'urf) yang turun-temurun dikenal dan dilakukan oleh masyarakat, baik itu perbuatan maupun perkataan. Adat kebiasan (al-'urf) inilah mempunyai peranan yang sangat penting sebagai salah satu dalil untuk menetapkan hukum syara', yaitu dikenal dengan istilah al-adah al-muhakkamah (adat kebisaan di tengah-tengah masyarakat bisa menjadi hukum). ${ }^{26}$

Pada dasarnya praktik pohulo'o adalah sebuah kebiasaan yang turun-temurun dilakukan oleh masyarakat Gorontalo, khususnya masyarakat petaninya. Praktik pohulo'o ini adalah bagian dari kegiatan bermuamalah yang mengandung unsur-unsur sosial yang sangat tinggi. Berikut akan diuraikan praktik pohulo'o relevansinya dengan ajaran hukum Islam.

\footnotetext{
${ }^{25}$ H. Dedi K. Usman, Tokoh Adat Gorontalo, Focus Group Discussion, di Grand City Hotel, Gorontalo, tanggal 4 Oktober 2017.

${ }^{26}$ Asjmuni A. Rahman, Qaidah-Qaidah Fiqh, Cet. I, (Jakarta: Bulan Bintang, 1976), h. 35.
} 


\section{Relevansi dalam Akad Pohulo'o}

Hal utama yang menjadi prinsipil dalam melaksanakan suatu transaksi ialah keabsahan akad. Ketentuan-ketentuan yang harus dipenuhi dalam keabsahan akad berdasarkan rukunnya menurut sistem hukum ekonomi syariah, yaitu aqid (pengggadai dan pemegang gadai), shigat (ijab qabul), marhun (barang gadai); dan marhun bih (hutang). ${ }^{27}$

Praktik pohulo'o yang dilaksanakan oleh masyarakat petani Gorontalo dalam segi rukun telah berkesesuaian dengan konsep al-rahn dalam sistem hukum ekonomi syariah, di mana telah memenuhi unsur-unsur, yaitu: (a) penggadai (tampohulo'o); (b) pemegang gadai (popohulo'o); (c) barang jaminan (upilohulo'o), (d) hutang (mobuli); (e) ijab qabul (dandialakaji). Sedangkan berkaitan dengan syarat-syarat gadai (rahn) menurut hukum ekonomi syariah, yaitu:

\section{a. Aqidain (orang yang berakad)}

Syarat bagi aqid dalam pelaksanaan akad gadai ialah aqid harus memiliki kecakapan (ahliyah), ${ }^{28}$ ialah orang yang cakap untuk melakukan suatu perbuatan hukum sesuai dengan ketentuan syariat Islam, yaitu berakal dan balig. Selain itu, aqid tidak berstatus dalam pengampuan (mahjur'alaih). ${ }^{29}$ Bahwa dalam hal praktek gadai sawah tersebut dilaksanakan oleh rahin (penggadai) dan murtahin (pemegang gadai) yang memiliki kecakapan, baik dari segi fisik maupun dari segi mental, serta lahan sawah yang digunakan sebagai jaminan merupakan lahan milik rahin sendiri.

Praktik pohulo'o yang dilakukan oleh masyarakat petani Gorontalo dihadiri oleh para pihak, yaitu penggadai (tampohulo'o) dan pemegang gadai (popohulo'o), di mana kedua belah pihak tersebut telah memiliki syarat kecakapan hukum, berakal dan balig.

b. Marhun (barang yang digadaikan)

Ulama Syafi'iyah menyebutkan bahwa barang yang digadaikan (marhun) hendaknya memiliki 3 (tiga) syarat, yaitu: (1) barang itu bukan hutang, karena barang hutang tidak dapat digadaikan; (2) penetapan kemilikian penggadai atas barang yang digadaikan tidak terhalang; dan (3) barang yang digadaikan bisa dijual apabila sudah tiba masa pelunasan hutang gadai. ${ }^{30}$

Juga diungkapkan oleh Rahmat Syafi'i bahwa pada umumnya barang gadai (marhum), yaitu: (1) harus dapat diperjualbelikan; (2) harta yang bernilai; (3) bisa dimanfaatkan secara syariah; (4) harus diketahui keadaan fisiknya, maka piutang diterima secara langsung; dan (5) harus dimiliki oleh rahin (penggadai/ peminjam), atau setidaknya harus seizin pemiliknya. ${ }^{31}$ Di sini tampak bahwa syarat sah gadai adalah harus ada jaminan yang berkriteria jelas dalam serah terima dan orang yang menggadaikan wajib menyerahkan barang jaminan kepada yang menerima gadai.

Penguasaan atau penerimaan barang yang digadaikan (upilohulo'o) telah sesuai dengan firman Allah swt. dalam QS al-Baqarah/2: 283. Penguasaan atau penerimaan barang yang digadaikan dalam Islam terdapat perselisihan pendapat di kalangan ulama

\footnotetext{
${ }^{27}$ Ahmad Wardi Muslich, Fiqhi Muamala, Cet.I, (Jakarta: Sinar Grafatika Offset, 2010), h. 290.

${ }^{28}$ Gufron A. Mas'adi, Fiqh Muamalah Kontekstual (Jakarta: PT. Raja Grafindo Persada, 2002), h. 78 .

${ }^{29}$ Gufron A. Mas'adi, Fiqh Muamalah Kontekstual,.. h. 79.

${ }^{30}$ Muhammad Ibn Rusyd, Bidayah al-Mujtahid, alih bahasa Imam Ghazali Syaid dan Ahmad Zaidun, Bidayatul Mujtahid, Cet. III, (Jakarta: Pustaka Imani, 2007), h. 196.

${ }^{31}$ Rahmat Syafi'i, Fiqh Muamalah, Cet. III, (Bandung: Pustaka Setia, 2006), h. 168.
} 
terkait penguasaan barang gadai itu merupakan syarat kelengkapan atau syarat sahnya gadai.

Imam Malik berpendapat bahwa barang gadai (marhum) itu sebagai syarat kelengkapan, akad gadai itu sudah mengikat dan orang yang menggadaikan sudah dipaksa untuk menyerahkan barang, kecuali bila pemegang gadai (murtahin) tidak mau adanya penentuan demikian. Imam Malik menkiaskan gadai dengan akad-akad lain yang mengikat dengan adanya ucapan, dan jika barang gadai (marhum) beralih kepada kekuasaan orang yang menggadaikan dengan jalan pinjaman (ariyah), penitipan atau lainnya, maka akad gadai tersebut tidak mengikat lagi. ${ }^{32}$

Menurut Imam Abu Hanifah, Imam Syafi'i, dan golongan Zahiri berpendapat bahwa penguasaan barang itu termasuk syarat sahnya gadai. Pendapat ini disebabkan selama belum terjadi penguasaan, akad gadai itu mengikat orang yang menggadaikan (rahin). ${ }^{33}$ Seseorang yang menggadaikan barang dengan syarat, ia akan membawa haknya pada saat jatuh tempo, dan jika tidak maka barang tersebut menjadi milik penerima gadai (murtahin). Fukaha dalam hal ini sependapat bahwa syarat tersebut mengharuskan batalnya gadai, sebab apabila rahin menggadaikan suatu barang kepada murtahin, maka kemanfaatan dari barang tersebut itu sepenuhnya milik rahin, begitu pula kerugian atau kerusakannya berada dalam tanggungan rahin. ${ }^{34}$ Pandangan ini sejalan dengan sabda Rasulullah saw:

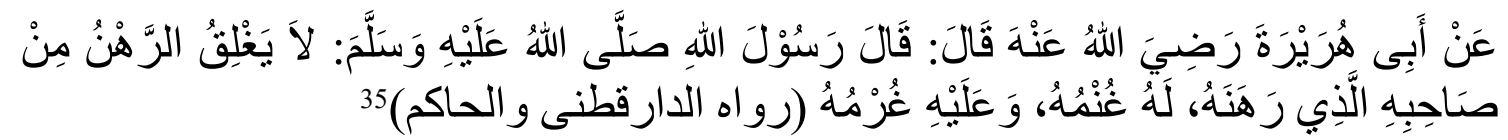

Artinya:

Dari Abu Hurairah ra. berkata bahwa Rasulullah saw. bersabda: barang gadaian tidak menutup pemilik yang menggadaikannya, keuntungan untuknya, dan kerugiannya menjadi tanggungannya (HR al-Darruquthni dan al-Hakim).

Terlepas dari adanya perbedaan pandangan para ulama di atas, maka pada prinsipnya praktik pohulo'o pada masyarakat petani Gorontalo dalam hal barang yang digadaikan (upilohulo'o) telah sesuai dengan sistem hukum ekonomi syariah, yaitu barang gadaian (upilohulo'o) sepenuhnya diserahkan kepada pemegang gadai (popohulo'o). Barang gadai (upilohulo'o) itu menjadi jaminan atas hutang yang telah dibuatnya.

Pada masyarakat petani Gorontalo yang menjadi barang gadai (popohulo'o) pada umumnya berupa sawah yang produktif. Sawah yang mudah teraliri dan sulit teraliri air serta sawah yang jauh dari jalan atau dekat dari jalan sangat mempengaruhi pinjaman dana yang akan diperoleh oleh penggadai (tampohulo'o). Dengan kata lain bahwa barang gadai (popohulo'o) itu haruslah bernilai dan dapat dimanfaatkan.

\section{c. Sighat Akad (Ijab Qabul)}

\footnotetext{
${ }^{32}$ Muhammad Ibn Rusyd, Bidayah al-Mujtahid, alih bahasa Imam Ghazali Syaid dan Ahmad Zaidun, Bidayatul Mujtahid, h. 197.

${ }^{33}$ Muhammad Ibn Rusyd, Bidayah al-Mujtahid, alih bahasa Imam Ghazali Syaid dan Ahmad Zaidun, Bidayatul Mujtahid, h. 197.

${ }^{34}$ Ismail Yakub, Al-Umm, Cet. I, (Kuala Lumpur: Victory Agencie, 1989), h. 366.

${ }^{35}$ Al-Hafiz ibn Hajar al-Asqalani, Bulugul Maram, Cet. II, (Jakarta: Pustaka As-Sunnah, 2007), h. 503.
} 
Sighat menurut istilah fukaha adalah perkataan antara ijab dan qabul secara yang dibenarkan syara dan menetapkan kerelaan keduanya (kedua belah pihak). ${ }^{36}$

Rukun gadai akan sah apabila disertai ijab dan qabul, sedangkan ijab dan qabul adalah sighat aqdi atas perkataan yang menunjukkan kehendak kedua belah pihak. Misalnya "Saya gadaikan barang ini kepada Saudara untuk hutangku yang sekian kepada Engkau," yang menerima menjawab: "Saya terima barang ini." Olehnya itu sighat aqdi harus memenuhi 3 (tiga) syarat, yaitu: (1) harus terang pengertiannya; (2) harus berkesesuaian antara ijab dan qabul; dan (3) memperlihatkan kesungguhan dari pihakpihak yang bersangkutan. ${ }^{37}$

Praktik pohulo'o yang dilakukan oleh masyarakat petani Gorontalo cukup mudah dengan langsung mendatangi pihak pemegang gadai (popohulo'o) dan mengutarakan maksudnya untuk melakukan pinjaman dengan barang jaminan dan mengutarakan jangka waktu pelaksanaan gadai tersebut. Selain itu, praktik pohulo'o, ada yang dilakukan secara tertulis dan secara lisan. Secara tertulis yaitu dengan adanya surat gadai yang dilakukan oleh yang menggadaikan sama yang menerima gadai, dengan dihadiri oleh saksi-saksi, dan biasanya dibuat di atas materai dan ditanda tangani oleh kedua belah pihak, serta saksi-saksi. Sedangkan secara lisan, dilakukan apabila antara kedua belah, baik penggadai (tampohulo'o) maupun pemegang gadai (popohulo'o) saling mengikat kepercayaan dalam pelaksanaan hak dan kewajiban masing-masing. ${ }^{38}$

\section{d. Marhum Bih (Hutang)}

Hutang (marhum bih) merupakan hak yang wajib diberikan kepada pemiliknya, yang memungkinkan pemanfaatannya, artinya apabila barang tersebut tidak dapat dimanfaatkan, maka tidak sah, dan dapat dihitung jumlahnya. ${ }^{39}$ Selain itu, hutang yang digunakan haruslah bersifat tetap, tidak berubah dengan tambahan bunga atau mengandung unsur riba. ${ }^{40}$

Pada dasarnya yang menjadi obyek gadai (upilohulo'o) pada tradisi pohulo'o pada masyarakat petani Gorontalo adalah berupa tanah, baik itu dalam bentuk perkebunan maupun persawahan. Hutang (mobuli) dalam praktik pohulo'o tidak bisa sesuai keinginan dari penggadai (tampohulo'o) saja, namun pemegang gadai (popohulo'o) juga memperhitungkan luas dari objek gadai (upilohulo'o) tersebut, yaitu uang gadai tidak boleh melebihi harga jual dari objek gadai (upilohulo'o) tersebut, dalam artian tergantung dari objek gadai (upilohulo'o) tersebut. Selain itu, dalam praktik pohulo'o juga sering terjadi penambahan hutang gadai, dalam hal ini biasanya tidak boleh lebih besar dari harga gadai yang pertama.

\section{Relevansi dalam Pemanfaatan Barang Pohulo'o}

Pada dasarnya barang gadai tidak boleh diambil manfaatnya, baik oleh pemiliknya maupun oleh penerima gadai. Hal ini disebabkan status barang tersebut hanya sebagai jaminan utang dan sebagai amanat bagi penerimanya. Apabila mendapat izin dari masing-

${ }^{36}$ T. M. Hasbi Ash-Shiddieqi, Pengantar Fiqih Muamalah, Cet. I, (Jakarta: Pustaka Rizki Putra, 1997), h. 26.

${ }^{37}$ T. M. Hasbi Ash-Shiddieqi, Pengantar Fiqih Muamalah, h. 31.

${ }^{38}$ Lihat QS. al-Baqarah/2: 282-283.

${ }^{39}$ Heri Sudarsono, Bank dan Lembaga Keuangan Syariah (Yogyakarta: Ekonosia Kampus Fakultas Ekonomi Universitas Islam Indonesia, 2004), h. 161.

${ }^{40}$ Chairuman Pasaribu dan Suhwardi K. Lubis, Hukum Perjanjian dalam Islam, Cet. II, (Jakarta: Sinar Grafika, 1996), h. 142. 
masing pihak yang bersangkutan, maka barang tersebut boleh dimanfaatkan. Oleh karena itu, agar di dalam perjanjian gadai itu tercantum ketentuan jika penggadai atau penerima gadai meminta izin untuk memanfaatkan barang gadai, maka hasilnya menjadi milik bersama. Ketentuan ini dimaksudkan untuk menghindari harta benda tidak berfungsi atau mubazzir.

Akad gadai bertujuan untuk meminta kepercayaan dan menjamin utang, bukan mencari keuntungan dan hasil. Selama hal itu keadaannya demikian, maka orang yang memegang gadai (murtahin) dapat memanfaatkan barang yang digadaikan, sekalipun diizinkan oleh orang yang menggadaikan (rahin). Menurut Sayyid Sabiq, tindakan memanfaatkan barang gadaian tak ubahnya qiradh yang mengalirkan manfaatnya, dan setiap bentuk qiradh yang mengalirkan manfaat adalah riba. ${ }^{41}$

Dalam pengambilan manfaat barang-barang yang digadaikan para ulama berbeda pendapat, di antaranya jumhur fukaha dan Ahmad. Jumhur fukaha berpendapat bahwa murtahin tidak boleh mengambil suatu manfaat barang barang gadaian tersebut, sekalipun rahin mengizinkannya, karena hal ini termasuk kepada utang yang dapat menarik manfaat, sehingga bila dimanfaatkan termasuk riba. Rasulullah saw. bersabda:

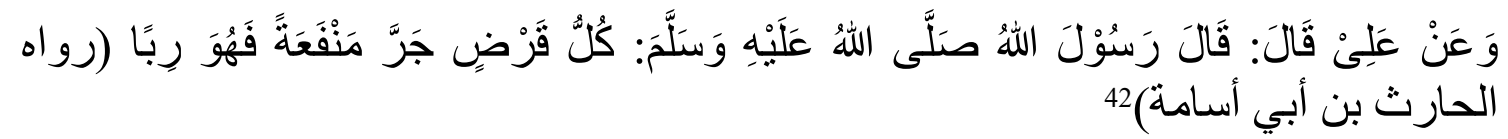

Artinya:

Dari Ali berkata bahwasanya Rasulullah saw. bersabda: setiap utang yang menarik manfaat adalah termasuk riba (HR Harits bin Usamah).

Muhammad Syafi'i Antonio berpandangan bahwa hadis di atas adalah berlaku bagi gadaian yang bukanlah binatang yang biasa ditunggangi atau diperah susunya, maka pemegang gadai (murtahin) boleh mengambil manfaat darinya sebagai kompensasi biaya yang dikeluarkan untuknya. Begitu juga halnya apabila barang gadai (marhum) berupa kendaraan, maka harus membelikan bahan bakar bensin. Pembolehan pemanfaatan barang gadai (marhum) terkait adanya pemeliharaan terhadap barang gadai (marhum) ${ }^{43}$

Imam Hanbali menjelaskan bahwa hadis tersebut di atas menunjukkan bahwa pengambilan manfaat pada benda-benda gadai ditekankan pada biaya atau tenaga pemeliharaan, sehingga bagi yang memegang barang gadai (murtahin) memiliki tugas tambahan. Pemegang gadai (murtahin) berkewajiban memberikan makanan bila barang gadai itu berupa hewan, jika harus mengisi bensin apabila barang gadaian berupa kendaraan, dan jika barang gadaian berupa rumah, maka membersihkan dan memperbaikinya jika diperlukan. ${ }^{44}$ Imam Maliki berpendapat bahwa gadai wajib dengan akad (setelah akad), penggadai (rahin) dipaksakan untuk menyerahkan barang gadai (marhum) untuk dipegang oleh penerima gadai (murtahin). Jika marhum sudah berada di tangan murtahin, diperbolehkannya murtahin memanfaatkan marhum atas izin rahin atau disyaratkan ketika akad. ${ }^{45}$

\footnotetext{
${ }^{41}$ Sayyid Sabiq, Fiqh Sunnah, alih bahasa H. Kamaludin A. Marjuki, Fiqhi Sunnah (Bandung: PT. Almaarif, 1996), h. 141.

${ }^{42}$ Hajar al-Asqalani, Bulughul Maram (Surabaya: Mutiara Ilmu, 1995), h. 364.

${ }^{43}$ Muhammad Syafi'i Antonio, Bank Syariah dari Teori ke Praktik (Jakarta: Gema Insani, Press, 2001), h. 186.

${ }^{44}$ Ibn Qudamah, Al-Mugni, Jil. 6 (Bairut: Dar al-Kitab Al-Araby, 1980), h. 432-433

${ }^{45}$ Isnawati Rais dan Hasanudin, Fiqh Muamalah dan Aplikasinya Pada Lembaga Keuangan Syariah, Cet. I, (Jakarta: Lembaga Penelitian UIN Syarif Hidayatullah, 2011), h. 227.
} 
Pohulo'o pada masyarakat petani Gorontalo yang menjadikan sawah atau ladangnya sebagai barang jaminan gadai (upilohulo'o) atas pinjaman yang diterima oleh orang yang menggadaikan (tampohulo'o) dari orang yang memegang gadai (popohulo'o). Dalam tradisi pohulo'o ada 2 (dua) model menggadai, yaitu: Pertama, pemegang gadai (popohulo'o) berhak memanfaatkan dan mengambil manfaat dari barang jaminan gadai (upilohulo'o) yang berupa sawah yang telah digadaikan tersebut selama penggadai (tampohulo'o) belum melunasi hutangnya (mobuli); dan Kedua, penggadai (tampohulo'o) dapat memanfaatkan barang gadai (upilohulo'o) berupa sawah atau ladang dengan sistem pajaki, yaitu menyewa barang gadai (upilohulo'o) -nya tersebut. Di sini tampak adanya pergeseran dari posisi penggadai (tampohulo'o) menjadi posisi penyewa. Praktik ini pada prinsipnya disepakati pada awal terjadinya akad perjanjian pohulo'o tersebut.

Selain itu juga ketika mencermati praktik pohulo'o dalam masyarakat petani Gorontalo, maka secara tekstual tidak sesuai dengan teks daripada kedua hadis tersebut di atas, karena praktik yang dilakukakan adalah barang gadainya berupa sawah atau tanah. Di sini tentunya sawah atau tanah dalam kondisi tidak ditanami.

Menurut Imam Syafi'i bahwa barang gadaian itu tidak menutup hak atas pemiliknya, yaitu orang yang menggadaikan untuk mengambil manfaatnya. Dengan demikian, orang yang menggadaikan tetap berhak atas segala hasil yang ditimbulkan dari barang gadaian dan bertanggung jawab atas segala resiko yang menimpa barang tersebut. Sedangkan pemegang gadai hanyalah menguasai barang jaminan sebagai kepercayaan atas uang yang telah dipinjamkannya sampai waktu yang telah ditentukan pada waktu akad. $^{46}$

Berdasarkan pendapat-pendapat di atas, maka pada dasarnya barang gadai (marhum) tidak boleh diambil manfaatnya, baik oleh penggadai (rahin) maupun pemegang gadai (murtahin). Hal ini disebabkan status hanya sebagai jaminan atas hutang dan sebagai amanat bagi murtahin. Namun apabila mendapat izin dari masing-masing pihak yang berakad, maka marhum boleh dimanfaatkan. Di sini rahin tidak memiliki barang secara sempurna yang memungkinkan melakukan perbuatan hukum karena barangnya sudah digadaikan. Sedangkan murtahin hanya pada keadaan atau sifat kebendaannya yang mempunyai nilai, tetapi tidak pada pemanfaatan atau pengumutan hasilnya. Murtahin hanya berhak menahan marhum, tetapi tidak berhak menggunakan atau memanfaatkan hasilnya sebagaimana rahin tidak berhak menggunakan barangnya, tetapi sebagai rahin apabila marhum itu mengeluarkan hasil, maka hasilnya tentunya menjadi milik rahin.

Jika mencermati pemanfaatan barang gadai (upilohulo'o) dalam praktik pohulo'o, maka diketemukan adanya relevansi-relevansi dengan konsep rahn menurut hukum ekonomi syariah, di mana pemanfaatan boleh dilakukan, baik penggadai tampohulo'o) maupun pihak pemegang gadai (popohulo'o) berdasarkan kesepakatan yang telah dibuat sebelumnya.

Islam sebagai sebuah ajaran yang menerapkan sistem dalam kehidupan manusia, maka tidak bisa dipisahkan dengan adat istiadat dan kebiasaan masyarakat. Budayabudaya tersebut dalam Islam dikenal dengan al- 'urf. Hasbi Ash-Shiddieqi menyebutkan bahwa al-'urf adalah adat kebiasaan yang dipandang baik oleh akal dan diterima tabiat

"66Imam Syafi'i, Ringkasan Kitab Al-Umm, Jil. 3 (Jakarta: Pustaka Azzam, 2010), h. 167. 
manusia yang sejahtera. ${ }^{47}$ Syariat Islam pula mengakui al- $u r f$ sebagai sumber hukum sebab adat kebiasaan telah memainkan peranan penting dalam hubungan dan ketertiban sosial di kalangan masyarakat.

Mencermati puholo'o sebagai tradisi yang turun-temurun dilakukan masyarakat Gorontalo pada prinsipnya adalah kegiatan yang sangat membantu pihak-pihak tertentu yang sementara kekurangan biaya atau ekonomi. Namun perlu juga diperhatikan bahwa praktik pohulo'o ini walaupun pada sisi lain masih adanya tidak kesesuaian dalam pemanfaatan barang gadai (upilohulo'o) yang terindikasi adanya eksploitasi kepada penggadai (tampohulo'o), namun selama telah menjadi kesepakatan dalam ijab qabul (dandia/akaji) dan adanya kerelaan kedua belah pihak, maka unsur mudharat-nya bisa terminimalisir dari unsur kemaslahatan yang diperoleh oleh penggadai (tampohulo'o).

\section{E. Penutup}

Praktik pohulo'o yang terjadi pada masyarakat petani Gorontalo pada dasarnya telah memenuhi unsur-unsur gadai $(\mathrm{rahn})$ dalam sistem hukum ekonomi syariah, baik terkait rukun maupun syarat-syaratnya. Pohulo'o ini merupakan praktik budaya yang dilakukan oleh masyarakat Gorontalo dengan mekanisme pihak penggadai (tampohulo'o) mendatangi secara langsung pemegang gadai (popohulo'o) dengan memberikan upilohulo'o (barang jaminan) atas hutang (mobuli) berdasarkan akad perjanjian atau ijab qabul (dandia atau akaji).

Relevansi pohulo'o dengan konsep rahn dalam sistem hukum ekonomi syariah terkait: Pertama, akad dimana unsur-unsur rukun dan syarat-syaratnya memiliki persamaan; Kedua, praktik pohulo'o dengan pemanfaatan barang gadai (upilohulo'o) kecenderungannya dilakukan oleh pemegang gadai (popohulo'o), walaupun penggadai (tampohulo'o) juga boleh memanfaatkannya. Namun dalam hal ini tergantung atas kesepakatan atau akad perjanjian yang telah dibuat. Perbedaan ini pada dasarnya dapat dilihat dari adanya perbedaan pandangan para fukaha dalam melihat jenis barang jaminan tersebut.

\section{Daftar Pustaka}

Aermadepa. "Perlindungan Hak Konstitusional Masyarakat Hukum Adat Minangkabau dalam Pelaksanaan Gadai Tanah Pertanian,“Jurnal Konstitusi, Vol. 13, No. 3, (September 2016).

Aliasman. "Pelaksanaan Gadai Tanah dalam Masyarakat Hukum Adat Minangkabau di Nagari Campago Kabupaten Padang Pariaman Setelah Berlakunya Pasal 7 UU No. 56/Prp/1960.“ Tesis. Semarang: Pascasarjana Universitas Diponegoro, 2005.

Anshori, Abdul Ghofur. Gadai Syari'ah di Indonesia. Yogyakarta: Gadjah Mada University Press, 2005.

Antonio, Muhammad Syafi'i. Bank Syariah dari Teori ke Praktik. Jakarta: Gema Insani, Press, 2001.

Al-Asqalani, Al-Hafiz ibn Hajar. Bulugul Maram. Cet. II. Jakarta: Pustaka As-Sunnah, 2007.

${ }^{47}$ Nourouzzaman Shiddieqi, Fiqih Indonesia: Penggagas dan Gagasannya, Cet. I, (Yogyakarta: Pustaka Pelajar, 1997), h. 122. 
Al-Asqalani, Hajar. Bulughul Maram. Surabaya: Mutiara Ilmu, 1995.

Badan Pusat Statistik Provinsi Gorontalo. Provinsi Gorontalo dalam Angka 2016, Gorontalo Province In Figures 2016. Gorontalo: Badan Pusat Statistik Provinsi Gorontalo, 2016.

Bahsan, M. Hukum Jaminan dan Jaminan Kredit Perbankan Indonesia. Jakarta: Rajawali Press, 2007.

Darwis, Rizal. "Sistem Bagi Hasil Pertanian Berbasis Kearifan Lokal Pada Masyarakat Petani Penggarap di Kabupaten Gorontalo Perspektif Hukum Ekonomi Islam," Penelitian. Gorontalo: Lembaga Penelitian IAIN Sultan Amai Gorontalo, 2016.

Hasan, M. Ali. Berbagai Macam Transaksi dalam Islam (Fiqh Muamalat), Ed. 1. Cet. I. Jakarta: PT RajaGrafindo Persada, 2003.

Ibn Rusyd, Muhammad. Bidayah al-Mujtahid. Alih Bahasa Imam Ghazali Syaid dan Ahmad Zaidun, Bidayatul Mujtahid. Cet. III; Jakarta: Pustaka Imani, 2007.

Ibn Qudamah. Al-Mugni. Jil. 6. Bairut: Dar al-Kitab Al-Araby, 1980.

Kementerian Agama RI. Ummul Mukminin: Al-Qur'an dan Terjemahan untuk Wanita. Jakarta: Penerbit Wali, 2008.

Mas'adi, Gufron A. Fiqh Muamalah Kontekstual. Jakarta: PT. Raja Grafindo Persada, 2002.

Muslich, Ahmad Wardi. Fiqhi Muamalah. Cet.I; Jakarta: Sinar Grafatika Offset, 2010.

Pasaribu Chairuman, dan Suhwardi K. Lubis, Hukum Perjanjian dalam Islam. Cet. II; Jakarta: Sinar Grafika, 1996.

Rahman, Asjmuni A. Qaidah-Qaidah Fiqh. Cet. I. Jakarta: Bulan Bintang, 1976.

Rais, Isnawati, dan Hasanudin, Figh Muamalah dan Aplikasinya Pada Lembaga Keuangan Syariah. Cet. I. Jakarta: Lembaga Peneliti UIN Syarif Hidayatullah, 2011.

Rasyid, Sulaiman. Fiqih Islam. Bandung: PT. Sinar Baru Algensindo, 1994.

Sabiq, Sayid. Fiqh Sunnah, Jilid 12. Jakarta: Pustaka Percetakan Offset, 1998.

Sabiq, Sayyid. Fiqh Sunnah. Alih Bahasa H. Kamaludin A. Marjuki, Fiqhi Sunnah (Bandung: PT. Almaarif, 1996.

Safrizal. "Praktek Gala Umong (Gadai Sawah) dalam Perspektif Syari'ah (Studi Kasus di Desa Gampong Daya Syarif Kecamatam Mutiara Kabupaten Pidie Provinsi Aceh),“ Jurnal Ilmiah Islam Futura, Vol. 15. No. 2, (Februari 2016).

Sasongko, Nur Ridwan Ari. "Gadai Tanah/ Sawah menurut Adat dari Masa ke Masa," Jurnal Repertorium, Vol. 1, No. 2, (November 2014).

Shiddieqi, Nourouzzaman. Fiqih Indonesia: Penggagas dan Gagasannya. Cet. I. Yogyakarta: Pustaka Pelajar, 1997.

Ash-Shiddieqi, T. M. Hasbi. Pengantar Fiqih Muamalah. Cet. I. Jakarta: Pustaka Rizki Putra, 1997.

Soekanto, Soerjono. Sosiologi: Suatu Pengantar. Jakarta: RajaGrafindo, 2009.

Sofhian dan Asna Usman Dilo. "Tradisi Pohulo’o Gorontalo dalam Tinjauan Fiqh,“ el Harakah, Vol. 15, No. 1 Tahun 2013. 
Sudarsono, Heri. Bank dan Lembaga Keuangan Syariah. Yogyakarta: Ekonosia Kampus Fakultas Ekonomi Universitas Islam Indonesia, 2004.

Sudiyat, Imam. Asas-Asas Hukum Adat: Bekal Pengantar. Yogyakarta: Liberty, 1981.

Suhendi, Hendi. Fiqh Muamalah. Cet. I. Jakarta: Rajawali Pers, 2014.

Syafi'i, Imam. Ringkasan Kitab Al-Umm. Jil. 3. Jakarta: Pustaka Azzam, 2010.

Syafi'i, Rahmat. Fiqh Muamalah. Cet. III. Bandung: Pustaka Setia, 2006.

Toneko, Soleman B. Struktur dan Proses Sosial. Cet. II. Jakarta: RajaGrafindo Persada, 1993.

Usman, Rachmadi. Hukum Jaminan Keperdataan. Jakarta: Sinar Grafika, 2003.

Yakub, Ismail. Al-Umm. Cet. I. Kuala Lumpur: Victory Agencie, 1989. 